\title{
Kontribusi Agroindustri Kelapa Sawit Terhadap Kesejahteraan Masyarakat Melalui Program Corporate Social Responsibility
}

\author{
Esli Zuraidah Siregar \\ Fakultas Dakwah dan Ilmu Komunikasi IAIN Padangsidimpuan \\ (E-mail: esli.zuraidah@gmail.com)
}

\begin{abstract}
Oil Palm agroindustry is a business entity engaged in the plantation and processing of oil palm. In the limited liability company act of 2007 explains that every company has a moral reponsibility to society and the corporate environment operates. Corporate social responsibility (CSR) is the obligation of a business entity to the stakeholders, society and environment or company ethics in basic principles of CSR, in addition to making as much profit as possible and make the company more developed, the company also has responsibility to provide prosperity to the community. In other words, the function of CSR is as an extension of the company's concern for the welfare of the economy, education, health and others. Tersebut corcern is applied through the contribution by the company to the community and surrouding environment. This research reveals the contribution of the palm oil industry in the field of economy, education and the implementation process of contribution applied through the palm oil CSR program.
\end{abstract}

Keywords: Contributions, Community Welfare, Corporate Social Responsibility

Abstrak: Agroindustri Kelapa Sawit merupakan badan usaha yang bergerak di bidang perkebunan dan pengolahan kelapa sawit. Dalam UU Perseroan terbatas tahun 2007, menjelaskan bahwa setiap perusahan memiliki tanggung jawab moral terhadap masyarakat dan lingkungan perusahaan beroperasi. Corporate Social Responsibility (CSR) atau Tanggungjawab Sosial Perusahaan (TSP) adalah kewajiban suatu badan usaha terhadap stakeholder, masyarakat dan lingkungan atau etika perusahasaan dalam menjalankan usahanya. Hal ini tercantum pada prinsip dasar CSR, selain mencari laba sebanyak mungkin (profit), dan membuat perusahaan lebih berkembang (Planet), perusahaan juga memiliki tanggung jawab untuk memberikan kesejahteraan kepada masyarakat (People). Dengan kata lain, fungsi CSR adalah sebagai perpanjangan tangan atas kepedulian perusahaan terhadap kesejahteraan ekonomi, pendidikan, kesehatan, dll. Kepedulian tersebut diaplikasikan melalui pemberian kontribusi oleh perusahaan kepada masyarakat maupun lingkungan sekitar. Penelitian ini mengungkap kontribusi Industri Kelapa Sawit dalam bidang ekonomi, pendidikan dan proses pelaksanaan kontribusi yang diaplikasikan melalui program CSR Kelapa Sawit.

Kata Kunci: Kontribusi, Kesejahteraan Masyarakat, Corporate Social Responsibility. 
69 Esli Zuraidah, Agroindustri Kelapa Sawit Terhadap Kesejahteraan Masyarakat

Melalui Program Corporate Social Responsibility

Jurnal At-Taghyir : Jurnal Dakwah dan Pengembangan Masyarakat Desa

Volume 1 Nomor 2 Juni 2019, h. 68-84

\section{A. Pendahuluan}

Proses pembangunan industri diharapkan menjadi salah satu cara meningkatkan produksi dalam memenuhi kebutuhan serta kesejahteraan masyarakat dalam bidang ekonomi. Pembangunan sektor industri ditujukan meningkatkan taraf hidup dan kemakmuran secara adil dan merata dengan memanfaatkan sumberdaya alam dan sumberdaya manusia. Peningkatan kesejahteraan masyarakat melalui pengembangan ekonomi, pendidikan, spiritual serta sarana dan prasarana, industri kelapa sawit mengambil andil di dalamnya, salah satunya Agroindustri Kelapa Sawit yang bergerak dalam bidang perkebunan dan pengolahan kelapa sawit. Agroindustri Kelapa Sawit diharapkan dapat membuka lapangan pekerjaan baru dan meningkatkan multiplier effeck, karena peningkatan multiplier effeck terjadi berbarengan dengan munculnya aktivitas-aktivitas perekonomian baru bagi masyarakat melalui keterlibatan agroindustri dalam peningkatan kesejahteraan masyarakat.

Etika perusahaan atau badan usaha menjadi perilaku utama dari para pelaku bisnis. Selama ini perusahaan dianggap sebagai lembaga yang memberikan keuntungan kepada masyarakat, dimana dalam pendekatan akutansi tradisional, perusahaan harus memaksimalkan labanya agar dapat memberikan sumbangan yang maksimal kepada masyarakat. ${ }^{1}$ Namun kualitas hidup seharusnya lebih menganut sikap kesadaran, karena pada dasarnya masyarakat adalah penentu utama peningkatan kualitas hidupnya. ${ }^{2}$ selain Tanggungjawab Sosial Perusahaan (TSP).

Corporate Social Responsibility (CSR) atau lebih dikenal sebagai Tanggungjawab Sosial Perusahaan (TSP) merupakan salah satu kegiatan wajib perusahaan dalam menjalankan tanggung jawab sosial kepada masyarakat yang telah diatur dalam UU No.40 tahun 2007 tentang Perseroan Terbatas (PT) pasal 74 dimana pada butir pertama dijelaskan "Perseroan yang menjalankan kegiatan usahanya di bidang dan/atau berkaitan dengan sumber daya alam wajib melaksanakan tanggung

\footnotetext{
${ }^{1}$ Henny dan Murtanto, Analisis Pengungkapan Sosial Pada lapangan Tahunan, Media Riset Akutansi, Auditing dan Informasi, Vol. 1, no 2:48, 2001, hlm. 22.

2 D.C Korten \& Sjahrir, Pembangunan Berdimensi Kerakyatan, Terj. A. Setiawan Abadi, (Jakarta: Yayasan Obor Indonesia, 1988), hlm. 116.
} 
70 Esli Zuraidah, Agroindustri Kelapa Sawit Terhadap Kesejahteraan Masyarakat

Melalui Program Corporate Social Responsibility

Jurnal At-Taghyir : Jurnal Dakwah dan Pengembangan Masyarakat Desa

Volume 1 Nomor 2 Juni 2019, h. 68-84

jawab sosial dan lingkungan". ${ }^{3}$ Selain kewajiban yang telah diatur oleh undang-undang, setiap perusahaan kini bersaing secara sehat untuk menciptakan citra yang baik di mata masing-masing baik konsumen serta masyarakat sekitarnya. Biasanya kegiatan ini menjadi senjata para praktisi PR menjadi daya tarik perusahaan ditengah-tengah masyarakat.

CRS merupakan komitmen usaha untuk bertindak secara etis, beroperasi secara legal dan berkontribusi untuk peningkatan ekonomi bersamaan dengan peningkatan kualitas hidup dari pegawai serta keluarganya, komunitas lokal dan masyarakat lebih luas. ${ }^{4}$ Mengacu pada Undang-Undang Nomor 25 Tahun 2007 tentang penanaman modal pasal $25 \mathrm{~b}$ yang menyatakan bahwa setiap penanaman modal wajib melaksanakan tanggung jawab sosial perusahaan. ${ }^{5}$ Konsep CSR menerangkan bahwa perusahaan atau industri kelapa sawit tidak hanya mempunyai tanggung jawab kepada pemegang saham saja, akan tetapi CSR juga memiliki tanggung jawab sosial kepada masyarakat dimana perusahaan tersebut menjalankan usahanya. Perusahaan mempunyai tanggung jawab sosial untuk mensejahterakan rakyat, baik melalui program khusus maupun dengan bantuan partisipasi masyarakat. CSR adalah komitmen perusahaan yang menekankan bahwa perusahaan harus mengembangkan etika bisnis dan praktik bisnis yang berkesinambungan secara ekonomi, sosial dan lingkungan, karena pada dasarnya aktivitas perusahaan tidak terlepas dari kontrak social dengan masyarakat. Oleh karena itu mayoritas perusahaan di berbagai dunia, salah satunya Negara Indonesia, melakukan kepedulian terhadap masyarakat. ${ }^{6}$

Sejahtera adalah suatu keadaan dimana tercipta tatanan atau tata kehidupan yang memadai dalam masyarakat, dan bukan sekedar kemakmuran pada kehidupan material, tetapi juga dalam kehidupan spiritual masyarakat. ${ }^{7}$ Secara formal, Kesejahteraan bermula ketika pendirian Departemen Sosial pada tanggal 19 Agustus 1945 dengan

\footnotetext{
${ }^{3}$ Undang-undang Republik Indonesia No 40 Tahun 2007 tentang Perseroan Terbatas.

${ }^{4}$ Edi Suharto, Pekerja Sosial di Dunia Industri Memperkuat CSR (Bandung: Alfabeta, 2011), hlm.16.

${ }^{5}$ Undang-undang Republik Indonesia No.25 Tahun 2007 tentang Penanaman Modal.

${ }^{6}$ Mukti Fajar, Tanggung Jawab Sosial Perusahaan di Indonesia, (Yogyakarta: Pustaka Pelajar, 2010), hlm. 45.

${ }^{7}$ Isbandi Rukminto Adi, Intervensi Komunitas Pengembangan Masyarakat Sebagai Upaya Pemberdayaan Masyarakat, (Jakarta: PT. Rajagrafindo, 2008), hlm. 45.
} 
71 Esli Zuraidah, Agroindustri Kelapa Sawit Terhadap Kesejahteraan Masyarakat Melalui Program Corporate Social Responsibility

Jurnal At-Taghyir : Jurnal Dakwah dan Pengembangan Masyarakat Desa

Volume 1 Nomor 2 Juni 2019, h. 68-84

tugas singkat yaitu urusan fakir miskin dan anak terlantar sesuai dengan pasal 34 UUD 1945. ${ }^{8}$ Pembangunan di Indonesia merupakan amanat, sebagaimana ditetapkan dalam UUD 1945, di mana tujuan negara Indonesia adalah untuk melindungi segenap bangsa Indonesia dan seluruh tumpah darah Indonesia, memajukan kesejahteraan umum, mencerdaskan kehidupan bangsa. ${ }^{9}$ Pembangunan ditujukan untuk mensejahterakan rakyat dari semua aspek kehidupan. Berbagai usaha dilakukan untuk mencapai tujuan tersebut, salah satunya melalui pemanfaatan sumberdaya alam dan sumberdaya manusia dengan pembangunan agroindustri yang banyak melibatkan masyarakat, salah satunya adalah agroindustri Kelapa Sawit.

Gambaran kondisi masyarakat sebelum berdirinya agroindustri Kelapa Sawit biasanya perlu mendapat perhatian karena rendahnya ekonomi masyarakat serta tingginya jumlah pengangguran. Sarana dan prasarana kurang memadai. Kurangnya kesadaran masyarakat akan pentingnya pendidikan, serta tidak adanya variasi kerja dalam masyarakat. Kondisi tersebut, menjadi sasaran utama kontribusi agroindustri Kelapa Sawit terhadap kesejahteraan masyarakat Hutaraja Tinggi. Dilihat dari keterlibatan Agroindustri Kelapa Sawit terhadap peningkatan ekonomi dan pendidikan masyarakat. Industri Kelapa Sawit Sawit, khususnya untuk daerah sekitar perusahaan telah berkontribusi terhadap peningkatan kesejahteraan masyarakat. Akan tetapi kontribusi yang telah diberikan Agroindustri Kelapa Sawit pada umumnya bersifat jangka pendek. Hal ini kurang sesuai dengan prinsip CSR yang mengacu pada pemberdayaan masyarakat jangka panjang. Dengan begitu penelitian yang berjudul "Kontribusi Agroindustri Kelapa Sawit Terhadap Kesejahteraan Masyaraka Melalui Program Corporate Sosial Responsibility (CSR)" perlu dilakukan, untuk melihat sejauhmana kontribusi yang diberikan Industri Kelapa Sawit terhadap kesejahteraan masyarakat.

B. Metode Penelitian

Penelitian ini merupakan penelitian lapangan (field research), yaitu penelitian yang dilakukan dalam kehidupan yang sebenarnya. Pada hakikatnya merupakan metode

\footnotetext{
${ }^{8}$ Fahrudin Adi, Pengantar Kesejahteraan Sosial, (Jakarta: Reflika Aditama, 2012). Hlm. 5

${ }^{9}$ Isbandi Rukminto Adi, Op.,cit. hlm. 45.
} 
72 Esli Zuraidah, Agroindustri Kelapa Sawit Terhadap Kesejahteraan Masyarakat Melalui Program Corporate Social Responsibility

Jurnal At-Taghyir : Jurnal Dakwah dan Pengembangan Masyarakat Desa

Volume 1 Nomor 2 Juni 2019, h. 68-84

untuk menemukan secara spesifik dan realitas tentang apa yang terjadi pada sesuatu saat di tengah-tengah masyarakat. Menggunakan pendekatan kualitatif metode deskriptif untuk menggambarkan secara mendalam dan konperhensif kontribusi Industri kelapa Sawit dalam peningkatan kesejahteraan masyarakat. Menggunakan sumber data primer dan sekunder. Teknik pengumpulan data menggunakan observasi, wawancara dan dokumentasi, data yang dikumpulkan kemudian diolah secara reduksi data, penyajian data, verifikasi data, kemudian ditarik kesimpulan dan diuji secara kualitatif, uji keabsahan data menggunakan triangulasi, dengan membandingkan antara data observasi, wawancara, dan dokumentasi.

\section{Hasil Penelitian}

1. Proses Pelaksanaan Program CSR Agroindustri Kelapa Sawit Terhadap Kesejahteraan Masyarakat:

a. Perencanaan

Perencanaan adalah memikirkan apa yang akan dikerjakan. Perencanaan CSR Agroindustri Kelapa Sawit dilakukan melalui beberapa proses, awalnya pihak perusahaan melakukan sosialisasi dan pendekatan kepada masyarakat sekitar perusahaan. Sosialisasi yang dilakukan biasanya melibatkan perangkat desa yang bersangkutan. Hal ini bertujuan untuk menjalin komunikasi yang baik antara pihak perusahaan dengan masyarakat. Perencanaan pembuatan program dilakukan dengan mempertimbangkan proposal-proposal bantuan yang diajukan masyarakat kepada perusahaan. Secara nyata perusahaan telah peduli terhadap keluhan-keluhan masyarakat, dengan menyampaikan setiap keluhan kepada dewan direksi. Apabila dalam musyawarah ini dewan direksi memberi persetujuan maka akan dilanjutkan dengan perencanaan lanjutan oleh badan Humas Industri Kelapa Sawit.

Untuk membuat suatu program yang baru perlu perencanaan yang matang, melalui proses yang sistematis. Hal ini sesuai dengan pendapat Ronni yang menyatakan bahwa perencanaan merupakan suatu proses pengambilan keputusan yang melibatkan berbagai tahapan sistematik dan beruntun dengan mempertimbangkan berbagai batasan- 
73 Esli Zuraidah, Agroindustri Kelapa Sawit Terhadap Kesejahteraan Masyarakat Melalui Program Corporate Social Responsibility

Jurnal At-Taghyir : Jurnal Dakwah dan Pengembangan Masyarakat Desa

Volume 1 Nomor 2 Juni 2019, h. 68-84

batasan sehingga dapat menghasilkan keputusan rasional. ${ }^{10}$ Setelah pengambilan keputusan oleh pihak humas perusahaan tentang proses yang akan diterapkan di lapangan maka pihak perusahaan akan melakukan sosialisasi dengan pengurus desa untuk menjelaskan program CSR dan tujuan dilaksanakannya. Hal ini merupakan bentuk survey awal dari program yang akan dilaksanakan sekaligus melakukan pendataan penerima maupun partisipan pelaksanaan.

Perencanaan program CSR Agroindustri Kelapa Sawit merupakan suatu kegiatan penetapan kegiatan yang akan dilaksanakan baik dari segi waktu dilaksanakan, jenis program dan proses pelaksanaannya, sebelum kegiatan dilaksanakan.

b. Pelaksanaan

Pelaksanaan merupakan aktualisasi dari perencanaan. Pada tahap pelaksanaan program CSR, pihak perusahaan melakukan sosialisasi. Sosialisasi pelaksanaan diperlukan untuk memperkenalkan kepada komponen perusahaan mengenai berbagai aspek yang terkait dengan implementasi CSR khususnya mengenai pedoman CSR. Tujuan utama dari pelaksanaan sosialisasi adalah agar program yang diimplementasikan mendapat dukungan dari seluruh komponen perusahaan. Dan melihat pelaksanaan program yang dilakukan apakah sejalan dengan pedoman CSR yang ada. Apabila terjadi ketidaksesuaian antara program yang akan dilaksanakan dengan konsep dasar CSR maka bisa saja konsep yang telah direncanakan dikaji ulang oleh pihak yang berwenang.

Dalam pelaksanaan CSR, pihak perusahaan melibatkan perangkat desa, baik itu dalam pembagian kupon kontribusi maupun dalam proses pembagian kontribusi tersebut. Hal ini merupakan salah satu usaha pihak perusahaan dalam membangun komunikasi yang baik dengan masyarakat setempat, khususnya perangkat desa yang berwenang di daerah tersebut. Sebelum penyaluran kontribusi dari perusahaan, biasanya perangkat desa telah membagikan kupon bantuan (jika ada) dan menghimbau warga yang akan menerima bantuan untuk hadir besok harinya di balai desa. Selain untuk menerima bantuan, pihak perusahaan juga bisa langsung bersosialisasi dengan masyarakat yang menerima kontribusi.

\footnotetext{
${ }^{10}$ Ronni M. Suabey, Makalah Teori Perencanaan (Publikasi), Universitas Sains dan Teknologi Jayapura Fakultas Tekhnik Sipil, hlm. 5
} 
74 Esli Zuraidah, Agroindustri Kelapa Sawit Terhadap Kesejahteraan Masyarakat

Melalui Program Corporate Social Responsibility

Jurnal At-Taghyir : Jurnal Dakwah dan Pengembangan Masyarakat Desa

Volume 1 Nomor 2 Juni 2019, h. 68-84

Pelaksanaan adalah suatu tindakan atau pelaksanaan sebuah rencana yang sudah disusun secara terperinci, implementasi biasanya dilakukan setelah perencanaan sudah dianggap siap. Secara sederhana perencanaan dianggap penerapan atau perluasan aktivitas yang saling menyesuaikan. ${ }^{11}$ Pelaksanaan CRS Industri Kelapa Sawit dilaksanakan dengan penerapan program-program yang telah dicanangkan sebelumnya. Pelaksanaan tersebut melalui proses yang cukup panjang. Dalam pelaksanaan CSR, menitoring, supervise dan pendampingan merupakan kunci keberhasilan implementasi program yang dilaksanakan. ${ }^{12}$ Untuk itu, pada pelaksanaan CSR, Agroindustri Kelapa Sawit selalu mengundang tokoh masyarakat, bahkan badan pemerintahan sebagai pendamping atau supervisi dalam pelaksanaan CSR.

c. Evaluasi

Tahap evaluasi dilakukan secara konsisten dari waktu ke waktu untuk melihat apakah program CSR yang diterapkan berjalan dengan lancar, sesuai dengan konsep CSR dan perencanaan yang telah dicanangkan. Pelaksanaan program CSR dipantau oleh pihak perusahaan dan beberapa tokoh masyarakat, serta badan pemerintahan di wilayah perusahaan. Pemantauan dan evaluasi diperlukan untuk mengetahui pencapaian tujuan program serta apakah terdapat penyimpangan yang membutuhkan tindak koreksi. Evaluasi program dilaksanakan untuk melihat tingkat keberhasil program yang dilakukan dan hambatan-hambatan yang dihadapi dalam pelaksanaannya. Merujuk pada evaluasi program yang dijelaskan oleh Suharsimin, yakni suatu kegiatan yang dimaksudkan untuk mengetahui seberapa tinggi tingkat keberhasilan dari kegiatan yang direncanankan. $^{13}$

2. Kontribusi Industri Kelapa Sawit dalam Bidang Ekonomi.

Beberapa kontribusi Agroindustri Kelapa Sawit di bidang ekonomisebagai berikut:

\footnotetext{
${ }^{11}$ Nurdin Usman, Konteks Implementasi berbasis Kurikulum, (Jakarta: PT. Raja Grapindo, 2002), hlm. 70

${ }^{12}$ Edi Suharto, Analisis Kebijakan Publik, (Bandung: Prenada, 2011), hlm. 14.

${ }^{13}$ Suharsimin Arikunto, Dasar-dasar Evaluasi Pendidikan, (Jakarta: Bumi Aksara, 2013), hlm. 
75 Esli Zuraidah, Agroindustri Kelapa Sawit Terhadap Kesejahteraan Masyarakat

Melalui Program Corporate Social Responsibility

Jurnal At-Taghyir : Jurnal Dakwah dan Pengembangan Masyarakat Desa

Volume 1 Nomor 2 Juni 2019, h. 68-84

a. Tenaga Kerja

Perekrutan tenaga kerja Industri Kelapa Sawit lebih mengutamakan putra daerah. Saat ini hampir $75 \%$ tenaga kerja yang bekerja di Industri Kelapa Sawit umumnya berasal dari masyarakat Sekitar Perusahaan berdiri. Namun dari tenaga ahli, sampai saat ini pihak perusahaan masih mempekerjakan orang-orang dari luar daerah, karena kurangnya SDM di daerah tersebut. Jumlah keseluruhan tenaga kerja mencapai 1.323 dengan fasilitas bervariasi, tergantung posisi dan jabatan yang diterimanya. Namun hampir sebahagian besar mendapat fasilitas rumah, baik ia karyawan perkebunan maupun karyawan pabrik, kecuali buruh harian yang digaji setiap harinya. Upah yang diberikan sesuai dengan UMR yang berlaku di daerah tersebut, selain upah sesui UMR, fasilitas yang memadai serta jaminan sosial, gaji lembur juga diberikan kepada pegawai yang memanfaatkan waktu bekerja diluar jam kerja.

Berdirinya industri kelapa sawit dapat meminimalisir jumlah pengangguran dengan menambah lapangan pekerjaan baru bagi masyarakat. Adanya lapangan pekerjaan baru diharapkan dapat membantu meningkatkan pendapatan masyarakat di wilayah perusahaan tersebut beroperasi.

\section{b. Koperasi}

Koperasi Perusahaan telah membantu masyarakat, seperti membuka usaha, membuka lahan baru, biaya pendidikan, dan pengembangan usaha yang telah dirintis. Koperasi Agroindustri kelapa Sawit menciptakan dampak positif terhadap pembangunan ekonomi masyarakat yang bertujuan untuk meningkatkan kemandirian ekonomi dan kesejahteraan sosial. Koperasi Agroindustri Kelapa Sawit wilayah Hutaraja Tinggi berdiri padan tahun 2005, jumlah anggota koperasi simpan pinjam setiap tahunnya semakin meningkat, sehingga alokasi dana yang harus disisihkan perusahaan setiap tahunnya juga semakin meningkat. Saat ini jumlah anggota koperasi telah mencapai 73 orang, 47 orang diantaranya berasal dari pegawai tetap di perusahaan tersebut.

Selain diuntungkan pinjaman dan penyimpanan, masyarakat juga diuntungkan dengan barang-barang yang dijual di koperasi dengan harga jual yang lebih murah dari pasaran. Harga barang yang dijual murah memiliki stok barang yang terbatas. Barang- 
76 Esli Zuraidah, Agroindustri Kelapa Sawit Terhadap Kesejahteraan Masyarakat

Melalui Program Corporate Social Responsibility

Jurnal At-Taghyir : Jurnal Dakwah dan Pengembangan Masyarakat Desa

Volume 1 Nomor 2 Juni 2019, h. 68-84

barang yang dijualbelikan di koperasi Agroindustri Kelapa Sawit Wilayah Hutaraja Tinggi antara lain minyak goreng ukuran $2 \mathrm{~L}$ dan kecambah /bibit sawit. Namun, barang yang diperjual belikan di koperasi memiliki stok yang terbatas dengan subsidi harga cukup besar. Dari selisih harga tersebut, pihak perusahaan telah membantu perekonomian masyarakat. Secara tidak langsung perusahaan telah membantu masyarakat mengatasi masalah ekonomi. Koperasi Agroindustri beroperasi digerakkan dan di fasilitasi oleh perusahaan. Dalam hal ini perusahaan berkontribusi kepada masyarakat melalui koperasi di perusahaan tersebut. Ditinjau dari konsep manfaat CSR, lebih dari aktivitas ekonomi, perusahaan sudah seharusnya memberikan manfaat yang lebih luas dan tidak statis, misalnya terkait bentuk philantropy dalam berbagai aspek sosial seperti pemberdayaan masyarakat dan lingkungan.

c. Bantuan Uang Tunai

Agroindustri Kelapa Sawit juga memberikan bantuan uang tunai dalam bidang ekonomi kepada masyarakat. Bantuan diberikan kepada masyarakat miskin dan kurang mampu yang terdapat di sekitar Perusahaan. Bantuan uang tunai yang diberikan oleh perusahaan kepada masyarakat terlihat seperti di bawah ini:

Tabel 1

Rekapitulasi Kontribusi Uang Tunai Agroindustri Kelapa Sawit

\begin{tabular}{|c|c|c|c|}
\hline No & Tahun & Jumlah Kontribusi & Penerima \\
\hline 1 & 2014 & Rp. $27,300,000$ & 175 Orang \\
2 & 2015 & Rp. $35,860,000$ & 220 Orang \\
3 & 2016 & Rp. $56,700,000$ & 280 Orang
\end{tabular}

Sumber: Agroindustri Kelapa Sawit Wilayah Hutaraja Tinggi

Jumlah bantuan semakin meningkat tiga tahun terakhir. Pemberian bantuan uang tunai diberikan sekali dalam setahun, pada bulan Ramadhan. Untuk jumlah bantuan yang dibagikan tergantung kesepakatan dari pihak perusahaan. Dalam Tabel berikut terlihat peningkatan Jumlah bantuan uang tunai dari tahun 2014-2017 : 
77 Esli Zuraidah, Agroindustri Kelapa Sawit Terhadap Kesejahteraan Masyarakat Melalui Program Corporate Social Responsibility

Jurnal At-Taghyir : Jurnal Dakwah dan Pengembangan Masyarakat Desa

Volume 1 Nomor 2 Juni 2019, h. 68-84

Tabel 2

Data Bantuan Uang Tunai Agroindustri Kelapa Sawit Wilayah Hutaraja Tinggi Tahun 2016

\begin{tabular}{|c|c|c|c|}
\hline No & Tahun & Nominal/orang & Jumlah Penerima \\
\hline 1 & 2014 & Rp. 156,000 & 175 \\
2 & 2015 & Rp. 163,000 & 220 \\
3 & 2016 & Rp. 189,000 & 300 \\
\hline
\end{tabular}

Sumber:Agroindustri Kelapa Sawit, data diolah

Bantuan uang tunai diberikan dengan tujuan membantu memenuhi kebutuhan pokok masyarakat kurang mampu. Bantuan ini adalah bentuk kepedulian perusahaan dalam bentuk gibah kepada masyarakat sekitar perusahaan. Berdasarkan hal tersebut secara ideal perusahaa telah berusaha menjadi etnik bisnis yang amanah kepada lingkungannya, sesuai dengan konsep CSR menurut perspektif Islam, ${ }^{14}$ (Muhammad Djakfar, 2011) dengan mengutamakan individu-individu atau kelompok yang membutuhkan dengan beberapa prosedur yang telah ditetapkan. Berdasarkan beberapa data terhimpun jumlah kontribusi yang diberikan Agroindustri Kelapa Sawit dalam bentuk uang tunai selama tiga tahun terakhir berjumlah Rp.119,860,000. Kontribusi tersebut sebagai bentuk tanggung jawab sosial perusahaan kepada masyarakat sekitar. Apabila ditinjau dari model atau pola CSR yang dijelaskan oleh Saidi dan Abidin, maka pola pelaksanaan bantuan uang tunai mengacu pada pola atau model keterlibatan langsung, yang berusaha menjalankan program CSR dengan menyelenggarakan kegiatan CSR sendiri. ${ }^{15}$ Bantuan yang diberikan sejalan dengan konsep Philantropy yang mengacu dalam bentuk Charity, atau sumbangan-sumbangan dalam bentuk dorongan amal, berdasarkan motivasi keagamaan dari suatu etnik bisnis. Hal ini juga sesuai dengan konsep CSR dalam perspektif Islam.

\footnotetext{
${ }^{14}$ Muhammad Djakfar, Etika Bisnis dalam Perspektif Islam, (Malang: UIN Malang Press, 2007), hlm. 160 .

15 Zaim Saidi dan Hamid Abidin, Menjadi Bangsa Pemurah: Wacana dan Praktek Kedermawanan Social Indonesia, (Jakarta: Pramedia, 2004), hlm. 59.
} 
78 Esli Zuraidah, Agroindustri Kelapa Sawit Terhadap Kesejahteraan Masyarakat

Melalui Program Corporate Social Responsibility

Jurnal At-Taghyir : Jurnal Dakwah dan Pengembangan Masyarakat Desa

Volume 1 Nomor 2 Juni 2019, h. 68-84

d. Peduli Pangan

Program peduli pangan merupakan program yang digalakkan Perusahaan dengan membagikan bahan pokok kepada masyarakat Hutaraja Tinggi. Bantuan dalam bentuk bahan makanan diberikan kepada masyarakat kurang mampu, yatim piatu dan fakir miskin sekali setahun. Bantuan ini bertujuan untuk meringankan beban sehari-hari mereka. tiga tahun terakhir Agroindustri Kelapa Sawit telah menyalurkan kepada 700 warga kurang mampu. bantuan tersebut tersebar beberapa daerah yang terletak di Kecamatan Hutaraja Tinggi. Proses penyaluran bantuan sembako sama halnya dengan bantuan lain, yakni melalui pejabat desa, kemudian pejabat desa yang akan menyalurkan langsung kepada masyarakat dengan didampingi pihak perusahaan. Penentuan penerima bantuan dilakukan melalui pertimbangan kebutuhan sehari-hari masyarakat.

Berdasarkan hal ini, Kontribusi Agroindustri Kelapa Sawit dalam bidang ekonomi untuk kesejahteraan masyarakat sesuai dengan rancangan perusahaan telah berjalan dengan baik, walaupun pada dasarnya kontribusi yang diberikan belum sesuai dengan harapan masyarakat kepada perusahaan. Berdasarkan penelitian yang dilakukan, pihak perusahaan telah memberikan kontribusi yang bertujuan untuk meningkatkan kesejahteraan masyarakat. Dapat disimpulkan pihak perusahaan telah mengaplikasikan salah satu konsep Piramida tanggung jawab sosial perusahaan yang dikembangkan oleh Archie B. Carrol, yakni: tanggung jawab kepada masyarakat (People), yang menyatakan bahwa setiap perusahaan harus memiliki kepedulian terhadap kesejahteraan masyarakat. ${ }^{16}$

\section{e. Pasar Murah}

Program pasar murah dilaksanakan sekali dalam setahun yakni pada bulan Ramadhan. Pasar murah Ramadhan adalah salah satu program yang telah lama diselenggarakan oleh pihak Agroindustri Kelapa Sawit daerah Hutaraja Tinggi. Pasar murah ini dilaksanakan secara serentak dibeberapa desa. Biasanya pihak perusahaan bekerja sama dengan pengurus desa dalam pelaksanaannya. Barang yang dijual belikan merupakan bahan pokok makanan yakni beras, minyak goreng, dan gula. Dua tahun

\footnotetext{
${ }^{16}$ Zaim Saidi dan Hamid Abidin, Menjadi Bangsa Pemurah: Wacana dan Praktek Kedermawanan Social Indonesia, (Jakarta: Pramedia, 2004), hlm. 59.
} 
79 Esli Zuraidah, Agroindustri Kelapa Sawit Terhadap Kesejahteraan Masyarakat Melalui Program Corporate Social Responsibility

Jurnal At-Taghyir : Jurnal Dakwah dan Pengembangan Masyarakat Desa

Volume 1 Nomor 2 Juni 2019, h. 68-84

terakhir pihak perusahaan melaksanakan pasar murah dengan sistem paket. Seperti yang terjadi pada tahun 2016 dan 2017. Pada tahun 2016 Industri Kelapa Sawit memberikan paket senilai Rp. 175.000,- yang terdiri dari beras $5 \mathrm{~kg}$, minyak goreng $2 \mathrm{~L}$, dan gula 2 $\mathrm{kg}$, telur 10 butir serta mie instan 10 bungkus dengan harga Rp. 25.000,-. Sedangkan pada tahun 2017, perusahaan mengurangi menambah takaran beras yang diberikan menjadi $7 \mathrm{~kg}$ dan mengurangi subsidi sebesar Rp. 25.000,-. Subsidi yang diberikan perusahaan mencapai Rp. 150.000,-. Pasar murah yang dilaksanakan diprioritaskan untuk warga kurang mampu dan fakir miskin yang terletak di sekitar perusahaan. Hal ini bertujuan untuk membantu warga yang kurang mampu. Kegiatan ini merupakan bentuk kepeduliaan perusahaan kepada masyarakat Hutaraja Tinggi.

Kegiatan pasar murah merupakan salah satu kegiatan CSR perusahaan yang diharmonisasikan dengan program pengentasan kemiskinan kementrian BUMN. Sebagaimana halnya dengan tujuan dilaksanakannya pasar murah tersebut yakni untuk meringankan beban hidup masyarakat. Program ini disambut antusias oleh masyarakat sekitar perusahaan. Karena mampu mengurangi pengeluaran, saat bulan puasa. Hal itu sejalan dengan tujuan yang diharapkan oleh perusahaan untuk membantu meringankan beban hidup masyarakat. Kontribusi tersebut merupakan bentuk kepedulian sosial pihak perusahaan kepada masyarakat sekitar perusahaan. Hal ini sesuai dengan prinsip CSR yang dijelaskan oleh Mu'min Nurmayana, yang mengatakan bahwa CSR merupakan suatu pendekatan di mana perusahaan mengintegrasikan kepedulian sosial dalam operasi bisnis mereka dengan para pemangku kepentingan berdasarkan prinsip kesukarelaan. ${ }^{17}$ CSR bermanfaat untuk memberdayakan masyarakat agar operasional perusahaan berjalan lancar. ${ }^{18}$ Jika hubungan perusahaan dengan masyarakat baik maka dipastikan perusaha akan bertahan lama dan dapat beroperasi dengan semestinya.

Keseluruhan bantuan Ekonomi tersebut apabila ditinjau dari konsep CSR, sebahagian besar bantuan tersebut digolongkan pada model atau pola CSR dengan keterlibatan langsung, yakni, setiap perusahaan menjalankan program CSR secara

\footnotetext{
${ }^{17} \mathrm{Mu}$ 'min Nurmayana, Corporate Social Responsibility dan Kontribusi bagi Pembangunan Berkelanjutan, Bandung: 2005, hlm. 5.

${ }^{18}$ Poerwanto, Corporate Social Responsibility: Menjinakkan gejolak sosial di era pornografi, (Yogyakarta: Pustaka Pelajar, 2010), hlm. 28.
} 
80 Esli Zuraidah, Agroindustri Kelapa Sawit Terhadap Kesejahteraan Masyarakat

Melalui Program Corporate Social Responsibility

Jurnal At-Taghyir : Jurnal Dakwah dan Pengembangan Masyarakat Desa

Volume 1 Nomor 2 Juni 2019, h. 68-84

langsung dengan menyelenggarakan sendiri kegiatan sosial atau dalam bentuk penyerahan sumbangan kepada masyarakat. ${ }^{19}$ Kontribusi Agroindustri Kelapa Sawit dalam bidang Pendidikan.

Kontribusi Agroindustri Kelapa Sawit dalam bidang pendidikan diaplikasikan melalui program CSR Peduli Pendidikan yang terdiri dari:

a. Penyaluran beasiswa dan pembagian alat tulis

Salah satu bentuk kontribusi Agroindustri Kelapa Sawit dalam bidang pendidikan dengan pembagian alat tulis kepada siswa/i SD diberikan satu kali dalam setahun yang merupakan bentuk kepedulian pihak perusahaan dalam memenuhi perlengkapan siswa/i, selain pembagian alat tulis, pihak perusahaan juga memberikan beasiswa kepada siswa/i berprestasi, namun kurang mampu. Program beasiswa telah ada sejak tahun 2000, pada tahun 2017 sudah berada di tahap ke 16 dengan jumlah penerima mencapai 4.564 penerima tahap 16 (2015-2016) adalah 354 orang, SD sebanyak 249 orang, SMP sebanyak 68 orang dan SMA sebanyak 37 orang. Pemberian beasiswa diutamakan untuk SD, SMP, SMA Negeri sekitar perusahaan serta anak-anak karyawan yang berprestasi. Penyaluran beasiswa berprestasi dan kurang mampu diberikan langsung kepada Siswa/i oleh pihak Industri Kelapa Sawit dengan didampingi oleh kepala sekolah atau perangkat sekolah lainnya.

Dalam tiga tahun terakhir beasiswa yang diberikan mengalami peningkatan angka dan jumlah penerimanya yakni pada tahun 2014-2016. Pada tahun 2014 jumlah penerima beasiswa dari Industri Kelapa Sawit berjumlah 92 orang yang terdiri dari SD 50 orang, SMP 24 orang, dan SMA berjumlah 18 dengan jumlah keseluruhan yang diberikan pada tahun tersebut sebesar Rp. 15,005,400. Tahun 2015 jumlah beasiswa yang disalurkan oleh Agroindustri Kelapa Sawit sebesar Rp. 18,010,400 yang terdiri dari SD 52 orang, SMP 32 Orang, dan SMA 21 orang dengan jumlah keseluruhan 105 Orang. Pada tahun 2017 Agroindustri Kelapa Sawit menyalurkan beasiswa dengan jumlah Rp. 23,160,000, SD sebanyak 55 orang, SMP sebanyak 20 dan SMA sebanyak 21. Jumlah nominal yang dibagikan sesuai dengan tingkat pendidikan dan nominal dari pihak perusahaan.

\footnotetext{
${ }^{19}$ Zaim Said dan Hamid Abidin, op., cit, hlm. 108
} 
81 Esli Zuraidah, Agroindustri Kelapa Sawit Terhadap Kesejahteraan Masyarakat

Melalui Program Corporate Social Responsibility

Jurnal At-Taghyir : Jurnal Dakwah dan Pengembangan Masyarakat Desa

Volume 1 Nomor 2 Juni 2019, h. 68-84

Kontribusi dalam bentuk beasiswa merupakan bentuk dukungan dan motivasi kepada pelajar berprestasi dan kurang mampu untuk menempuh pendidikan tinggi, walaupun kontribusi beasiswa yang diberikan pihak perusahaan masih jauh dari harapan masyarakat. Jumlah bantuan yang diberikan mengalami peningkatan dari tahun-tahun sebelumnya. Hal ini membuktikan kepedulian pihak perusahaan Kelapa Sawit peduli terhadap pendidikan masyarakat sekitar. Pemberian beasiswa dan buku tulis merupakan salah satu bentuk program peduli pendidikan yang digerakkan oleh CSR Agroindustri Kelapa Sawit untuk membantu meningkatkan pendidikan masyarakat yang digolongkan pada CSR keterlibatan langsung.

b. Tunjangan Guru Madrasah Diniyah Awaliyah (MDA)

Kontribusi dalam bentuk tunjangankepada guru MDA diberikan sejak 3 tahun terakhir. Bantuan ini diberikan sekali tiga bulan dengan jumlah Rp. 500.000 setiap guru. Bantuan ini telah beberapa kali dibagikan kepada guru-guru MDA yang berada disekitar perusahaan. Sampai tahun 2016, jumlah guru yang mendapat bantuan tersebut sebanyak 15 orang yang tersebar di desa Menanti, Aliaga, dan Parmainan. Kontribusi berbentuk tunjangan adalah salah satu bentuk kepedulian perusahaan kelapa sawit terhadap pendidikan, terutama pendidikan agama. Sejak pemberian kontribusi oleh Agroindustri Kelapa Sawit, guru MDA semakin sejahtera. Karena selain tunjangan yang diberikan sekali tiga bulan, pada bulan Ramadhan pihak perusahaan juga akan memberikan bonusan berupa uang tunai dan kain sarung kepada guru-guru MDA. Kepedulian perusahaan kepada masyarakat merupakan tanggung jawab muthlak yang harus dilaksanakan perusahaan selama perusahaan tersebut masih beroperasi. Hal ini diatur dalam Undang-undang perseroan No 40 Tahun 2007.

Konsep penyaluran kontribusi yang dilakukan Agroindustri Kelapa Sawit sesuai dengan pendapat Zaim Saidi dan Hamid Abidin, yang menyatakan bahwa salah satu pola CSR adalah dengan memberikan bantuan langsung kepada masyarakat, tanpa melalui perantara. ${ }^{20}$

\footnotetext{
${ }^{20}$ Zaim Saidi dan Hamid Abidin, Op.,cit, hlm. 108
} 
82 Esli Zuraidah, Agroindustri Kelapa Sawit Terhadap Kesejahteraan Masyarakat

Melalui Program Corporate Social Responsibility

Jurnal At-Taghyir : Jurnal Dakwah dan Pengembangan Masyarakat Desa

Volume 1 Nomor 2 Juni 2019, h. 68-84

\section{Pembahasan}

Model Corporate Social Responsibility (CSR) yang banyak dianut perusahaan pada saat sekarang ini, yakni:

1. Keterlibatan langsung.

Perusahaan menjalankan program CSR secara langsung dengan menyelenggarakan sendiri kegiatan social atau menyerahkan sumbangan ke masyarakat tanpa perantara. Untuk menjalankan tugas ini, sebuah perusahaan biasanya menugaskan salah satu pejabat seniornya, seperti coporate secretary atau public affair manager atau menjadi bagian dari tugas pejabat public relation.

2. Melalui yayasan atau organisasi social perusahaan.

Perusahaan mendirikan yayasan sendiri di bawah perusahaan atau groupnya. Model ini merupakan adopsi dari model yang lazim diterapkan di perusahaanperusahaan di Negara maju. Biasanya, perusahaan menyediakan dana awal, dana rutin atau dana abadi yang dapat digunakan secara teratur bagi kegiatan yayasan. Beberapa yayasan yang didirikan perusahaan diantaranya adalah yayasan Coca Cola Company, yayasan Rio Tinto (perusahaan pertambangan), yayasan dharma Bhakti Astra, yayasan Sahabat Aqua, GE Fund.

3. Bermitra dengan pihak lain.

Perusahaan menyelenggarakan CSR melalui kerjasama dengan lembaga social/organisasi non-pemerintah, instansi pemerintah, universitas atau media massa, baik dalam mengelola dana maupun dalam melaksanakan kegiatan sosialnya. Beberapa lembaga social yang bekerja sama dengan perusahaan dalam menjalankan CSR antara lain Palang Merah Indonesia (PMI), Yayasan Kesejahteraan Anak Indonesia (YKAI), Dompet Dhuafa, instansi pemerintah (Lembaga Ilmi Pengetahuan Indonesia/LIPI, Depdiknas, Depkes, Depsos), Universitas (UI, ITB, IPB, ikatan dinas), media massa (DKK kompas, kita peduli Indosiar)

4. Mendukung atau bergabung dalam suatu konsorsium.

Perusahaan turut mendirikan, menjadi anggota atau mendukung suatu lembaga social yang didirikan untuk tujuan social tertentu. Dibandingkan dengan model lainnya, pola ini lebih berorientasi pada pemberian hibah perusahaan yang bersifat "hibah pembangunan". Pihak konsorsium atau lembaga semacam itu yang dipercayai oleh 
83 Esli Zuraidah, Agroindustri Kelapa Sawit Terhadap Kesejahteraan Masyarakat Melalui Program Corporate Social Responsibility

Jurnal At-Taghyir : Jurnal Dakwah dan Pengembangan Masyarakat Desa

Volume 1 Nomor 2 Juni 2019, h. 68-84

perusahaan-perusahaan yang mendukungnya secara pro aktif mencari mitra kerjasama dari kalangan lembaga operasional dan kemudian mengembangkan program yang disepakati bersama. Variasi pola atau model CSR yang bervariasi memberikan dampak yang berpengaruh terhadap kesejahteraan masyarakat. Melalui berbagai model tersebut, CSR mampu berbagi dengan masyarakat, baik secara langsung maupun melalui perantara. Tetapi tujuannya tetap sama, yakni untuk memberikan tanggungjawab sosial perusahaan kepada masyarakat.

Dari data hasil penelitian di atas, CSR Industri kelapa sawit sebahagian besar menggunakan pola CSR dengan keterlibatan langsung, dilihat dari praktik CSR yang dijalankan perusahaan kepada masyarakat selama ini, yakni dengan melakukan peningkatan perekonomian masyarakat pemberdayaan tenaga kerja dari putra/putri daerah disekitar, Pemberian bantuan uang tunai, pendirian koperasi simpan pinjam dan pembagian bahan pokok makanan. Dari kontribusi yang diberikan perusahaan, hanya sebagaian kecil saja yang menggunakan pola lainnya, misalnya dengan bermitra dengan lembaga pendidikan yang ada di daerah tersebut untuk membantu biaya pendidikan masyarakat dan pembagian alata tulis dengan melibatkan tenaga kependidikan yang berada di wilayah tersebut. Industri kelapa sawit telah membuktikan bahwa, pihak perusahaan telah menjalankan amanah sebagai sebuah etika sebuah perusahaan kepada masyarakat dengan menjalankan tanggungjawab sosialnya sebagaimana sebuah badan usaha yang memikirkan dan memperhatikan kepentingan masyarakatnya.

\section{E. Kesimpulan}

Kontribusi Agroindustri Kelapa Sawit dalam bidang ekonomi direalisasikan melalui Koperasi, Pemberdayaan masyarakat sebagai tenaga kerja di industri perkebunan dan pengolahan, pemberian bantuan uang tunai kepada keluarga miskin dan kurang mampu, Program Peduli Pangan yang dikhususkan kepada keluarga kurang mampu, serta pasar Murah yang dilaksanakan untuk membantu memenuhi kebutuhan masyarakat miskin, kurang mampu dan anak yatim piatu. Kontribusi dalam bidang pendidikan diaplikasikan melalui program peduli pendidikan dengan membagikan beasiswa kepada siswa/siswi berprestasi dan kurang mampu, pembagian alat tulis kepada siswa/i kelas 1-3 SD Negeri yang disalurkan secara serentak sekali dalam 
84 Esli Zuraidah, Agroindustri Kelapa Sawit Terhadap Kesejahteraan Masyarakat

Melalui Program Corporate Social Responsibility

Jurnal At-Taghyir : Jurnal Dakwah dan Pengembangan Masyarakat Desa

Volume 1 Nomor 2 Juni 2019, h. 68-84

setahun, serta tunjangan untuk guru MDA yang disalurkan sekali tiga. Proses penyaluran kontribusi Agroindustri Kelapa Sawit dilakukan melalui beberapa tahapan, yakni tahapan Perencanaan, Pelaksanaan, dan Evaluasi. Secara keseluruhan kontribusi Agroindustri Kelapa Sawit telah membantu meningkatkan kesejahteraan masyarakat, baik dalam bidang ekonomi maupun pendidikan. Akan tetapi sebahagian besar kontribusi yang diberikan hanya berupa bantuan langsung, dan bersifat jangka pendek/tidak dalam bentuk pemberdayaan masyarakat yang bisa dimanfaatkan dalam jangka panjang.

\section{Daftar Kepustakaan}

Adi, Fahrudin Pengantar Kesejahteraan Sosial, Jakarta: Reflika Aditama, 2012.

Adi, Isbandi Rukminto, Intervensi Komunitas Pengembangan Masyarakat Sebagai Upaya Pemberdayaan masyarakat, Jakarta: PT. Raja Grapindo Persada, 2008.

Adi, Isbandi Rukminto Intervensi Komunitas Pengembangan Masyarakat Sebagai Upaya Pemberdayaan Masyarakat, Jakarta: PT. Rajagrafindo, 2008.

Arikunto, Suharsimin, ManajemenPenelitian, Jakarta: PT RinekaCipta. 2007.

Djakfar, Muhammad, Etika Bisnis dalam Perspektif Islam, Malang: UIN Malang Press, 2007.

Fajar, Mukti , Tanggung Jawab Sosial Perusahaan di Indonesia, Yogyakarta: Pustaka Pelajar, 2010

Henny dan Murtanto, Analisis Pengungkapan Sosial Pada lapangan Tahunan, Media Riset Akutansi, Auditing dan Informasi, Vol. 1, no 2:48, 2001.

Naqvi, Syed Nawab Kaidir Menggagas Ekonomi Islam, Yogyakarta: Pustaka Pelajar, 2003.

Saidi, Zaim dan Hamid Abidin, Menjadi Bangsa Pemurah: Wacana dan Praktek Kedermawanan Sosial Indonesia, Jakarta: Piramedia, 2004.

Suabey, Ronni M., Makalah Teori Perencanaan (Publikasi), Universitas Sains dan Teknologi Jayapura Fakultas Tekhnik Sipil.

Sugiyono, Metode Penelitian Kuantitatif dan Kualitatif, Bandung: Alfabeta, 2008.

Sugiyono, Memahami Penelitian Kualitatif. Bandung: ALFABETA, 2005.

Suharto, Edi Membangun Masyarakat Memberdayakan Rakyat. Bandung: Reflika Aditama, 2009.

Suharto, Edi, Pekerja Sosial di Dunia Industri Memperkuat CSR, Bandung: Alfabeta, 2011.

Undang-undang Republik Indonesia No. 40 Tahun 2007 tentang Perseroan Terbatas.

Undang-undang Republik Indonesia No. 25 Tahun 2007 tentang Penanaman Modal

Usman, Nurdin, Konteks Implementasi berbasis Kurikulum, Jakarta: PT. Raja Grapindo, 2002. 